\title{
MED23 Gene
}

National Cancer Institute

\section{Source}

National Cancer Institute. MED23 Gene. NCI Thesaurus. Code C20687.

This gene is involved in activation of Sp1 transcription. It also plays a role in suppression of metastasis. 